\title{
TRANSLATING PHATIC EXPRESSIONS
}

\author{
Jamal B.S. al-Qinai ${ }^{1}$
}

\begin{abstract}
Any conversational exchange can be informational or phatic. Occasional exchanges are of no lesser importance than the informative content of dialogue. One needs to establish the channel of communication by setting up a social environment conducive to the exchange of ideas among the participants. Such a strategy of showing politeness is intended to avoid face-threatening acts through the use of compliments and non-verbal gestures. Mistranslating the function of a given phatic communion expression might lead to problems ranging from the disruption of mundane daily small talk such as the break up of a courtship dialogue to grave consequences as the failure of crucial peace talks among belligerent nations. The paper explores the effect of misinterpreting culturally divergent phatic communion formulae in an English-Arabic context. Other sociolinguistic parameters such as topic, setting, age, sex and social status will be considered.
\end{abstract}

Keywords: Translating; Phatic; Polite.

\section{Introduction}

The notion that language is not merely referential but serves a communicative purpose with a definitive goal has led to the development of the study of 'language in use' or 'discourse'. The 'performative function' of language has thus taken central stage under the sociopragmatic approach. Additional notions such as 'face' and the concept of 'politeness' have shifted the focus to what interactants 'do' with discourse instead of what they 'mean' by a given utterance (Sanchez 2001: 591).

Conversation can be said to contain two elements, the informational and the phatic. The latter is part and parcel of the sociolinguistic repertoire of any society whereby some conventional formulaic expressions are used as a gambit to open or direct a conversation or to establish our distance from and express our feelings towards the other. The anthropologist Malinowski (1884-1942) coined the phrase 'phatic communion' to refer to this social function of language which arises in order to maintain rapport between people in line with the maxims of politeness. In other words, phatic communication is used to establish social relationships rather than impart factual information. In 1960, Jackobson, used the term "phatic function" to refer to the channel of communication that is established to maintain communication. Robins (1964: 30) used the term 'relevance and idle chatter' to refer to this aspect of human communication that reflects a courteous approach towards the other interlocutors and reflects one's

\footnotetext{
${ }^{1}$ This research was sponsored by Kuwait University Grant AE02/08
} 
ethnic background, kinship and social hierarchy. Coulmas (1979: 6) refers to phatic expressions as standard links between what people actually say and what sort of communicative functions their utterances serve to perform. Schneider (1988) introduced another term 'small talk' and developed grammars which characterize small talk in particular domains. Laver (1975) further analyzed small talk by describing the contexts in which it occurs while Cheepen (1988) studied topics typically used in such contexts. Holmes (1995), however, tackled the topic from a different angle; she concluded that Americans' responses to compliments are usually perceived as face-threatening acts, because the recipients, especially women, are obliged by social norms to appreciate them and at the same time show modesty.

The analysis of requests by Ervin-Tripp and Wolfson's study of compliments in American English as well as the contrastive investigation by Blum-Kulka, House and Kasper all point to a burgeoning interest in the field (Sanchez 2001: 594). Nevertheless, the majority of these early studies was ethnocentric in approach and remained heavily language-centered. In 1985, Wierzbicka carried out a contrastive analysis of requests in English and Polish in an attempt to detect culturally differentiated ways of speaking. She claims that different pragmatic norms reflect different cultural values. For instance, she associates the interrogative form of requests in English with the Anglo-Saxon tradition of individual freedom that guarantees the right to accept or reject a request (Wierzbicka 1985: 150). Similarly, Oleksy conducted an ethnographic study of compliment response in American English and South African English. He found out that American English speakers show a higher frequency of compliment response while South Africans prefer acceptance. Along the Whorfian hypothesis, he establishes a link between linguistic structural modes and the sociocultural patterns of the speaking community (Oleksy 1989: 220).

Within the same ethnocentric approach, several Arab researchers investigated the function of phaticity in certain regional dialects of Arabic. Nelson, el-Bakary and Al-Batal (1993) compared Egyptian and American Compliments while Al-Khasawneh explored the translatability of Jordanian phatic expressions into English. Mughazy (2000), on the other hand, conducted an oral discourse completion test to study the pragmatics of the evil eye formulaic compliments and the recipient's response strategies in the form of evasion, humor, complaint and confrontation.

The study of phatic communion is inherently part of discourse research which sets out "to make sense of or to interpret phenomena in terms of the meanings people bring to them" (Denzin \& Lincoln 2000: 3). Part of what the analyst has to do is to reimagine (i.e., interpret) the actual discourse of which the text-as-record is a very impoverished trace. While the semantic component of the text is relatively discernible by textual clues, the interpretation of the expressive-emotional aspect of phatic expressions requires extralinguistic and sociolinguistic references. Otherwise, the pragmatic core of the source language (SL) text may be lost and, therefore, ambivalence in the target language (TL) text may arise for the recipient reader. The misinterpretation and in effect the mistranslation of phatic expressions may misrepresent the author's communicative intention, the social context of the situation as well as the disposition or relationships of the participants in a given communicative act. 


\section{The constitution of phatic expressions}

The acts of greeting, leave-taking, thanking, apologizing and so on constitute a universal phenomenon. However, the linguistic realization of these acts, the content and rules of their performance may exhibit variations from one language to another depending on the particular values and beliefs of their users. Phatic expressions vary in their forms according to constitution and place of occurrence in a discourse. The conventional form of phatic communion requires the presence of interlocutors (an addressor and an addressee) a place, time and an occasion. The latter can be a simple casual chat or a special occasion such as birthdays, anniversaries, Christmas, graduation and many more. The forms of phatic interaction range from simple greetings and compliments, suggestions and advice, requests and appeals, promises and reminders to indirect warnings and threats. The goals, on the other hand, vary between achieving a sense of familiarity and group integration to realizing the outcome a given speech act.

Setting plays a decisive role in the volume and frequency of phatic communion. Kendon (1992: 329) discusses the correlation between phatic communion and the participants' arrangements. He postulates that participants arrange themselves into a particular spatial-orientational pattern and they cooperate to maintain such an arrangement throughout the conversational act. However, it should be pointed out that phatic communication is not constrained by the immediate spatial and temporal environment. Postcards, e-cards, e-mail, voice-mail and text messages provide convenient alternatives to face-to-face conversation.

Parent (2001: 600-1) considers some non-conventional phatic gambits. He cites the case of repetition as a positive politeness strategy. When an addressee repeats an utterance he has already heard, this is considered an overture of emotional agreement with the utterance and stresses interest. Sometimes, the speaker repeats certain parts of the request or elaborates with reasons for the request even after the addressee gives a positive response. This is done in order to soften the conversation by pulling the addressee to see the reasonableness of the request. Likewise, when the addressee interrupts the speaker's utterance only to complement it, this shows that the addressee is aware of the speaker's needs and both are in full agreement. Using ellipsis, on the other hand, indicates that the speaker and addressee share mutual knowledge. For example, a speaker may use a given number (e.g. SP 25) to refer to a watch being repaired at a clocksmith on the assumption that it is interpretable within a shared understanding between both interactants. Finally, diminutive forms are sometimes used to minimize the intensity of a face threatening act as they appear to have an element of selfhumbling and persuasion. Parent (2001: 601) cites the example of offering a carrier bag to a customer in Catalan by using the diminutive una bosseta 'a small carrier bag' in order to persuade the addressee that 'it's only a little carrier bag so you can't say no'.

Prior to, or at the beginning of, a conversation, participants often frame the event. That is, they make clear to each other the intended nature of the conversation-tobe. For the most part, the purpose of this small talk is to establish rapport and trust among the interlocutors and provide time for them to evaluate each other. According to Miller (1999: 2), all conversations contain phatic communion since one needs to set the tenor of the conversation and establish an attitude towards the speaker in order to take part in the communicative exchange. Yet, this does not undermine the fact that opening conversations are also purposeful in that they help the participants define their goal, whether to negotiate or be resolute, show positive feelings like affability and courtesy or 
take a negative hostile posture. It should also be made clear that the degree of phatic frequency varies according to topic and setting. Thus, business-oriented interviews and emergency calls have the lowest level of phatic clichés. For example, Gonzales (2001: $605)$ reports that emergency calls consist of disjunctive, fact-seeking sequence whose aim is to elucidate the location and nature of the emergency and dispatch the required remedy. In such settings, time is of the essence and there is no point in wasting the precious seconds in establishing unsolicited solidarity.

Conversational phatic expressions including honorifics and greetings constitute the most common type of spoken discourse that is intended to convey emotions, initiate a talk and sustain it. Rather than imparting information, they function to share feelings, create goodwill (or hostility), or set a pleasant (or offensive) social mood. In other words, they establish the tenor and attitudinal setting for a possible dialogue. Holmes (1995: 5) postulates that this strategy is used by polite people to "avoid obvious face threatening acts" and denote "non-imposing distancing behaviour". Indeed, without softening tactics like indirectness in the request (e.g. I wonder if you could...) or the use of politeness markers such as 'please', requests are intrinsically face-threatening since they involve the placement of an imposition on the addressee and an intrusion into his/her territory.

Since phatic communion is part and parcel of the cultural etiquette and the communicative framework of any given language, Crystal (1987: 10-11) remarks that cultures vary greatly in the topics which they permit as phatic communion. For example, the weather is not a universal conversation filler as one may find in traditional conversational routines in English. Likewise, in some cultures, utter silence performs the function of courteous formulaic expressions in others. In this regard, Darwish (2003) notes that translation interventionism is required to make the translation of [phatic expressions] conform to target language conventions and norms in terms of politeness, social distance and honorifics. He cites the example of the word "wife" which has several Arabic synonyms each indicating a different level of politeness and formality (بعلة ba'lah / زوجة zawğah / عقيلة / عaينة 'aqīlah / حرية harinah). The choice of any of the Arabic equivalents will determine the degree of deference shown to the addressee. On the other hand, Dickens (Dickens et al 2005: 30) finds that sometimes it is virtually impossible to mediate conversational routines as they constitute an integral part of cultural exoticism. He cites a sample of repetitive Arabic conversational salutations which can only be functionally rendered as 'hello' and 'how are you'.

Arabic ST

$$
\begin{aligned}
& \text { A: السلام عليكم 'assalāmu 'alaykum } \\
& \text { B: و عليكم السلام عa'alaykum 'assalām } \\
& \text { A: كيف الحال kayf 'alḥ̂̄l } \\
& \text { B: الحمد له 'alḥamdu lillāh } \\
& \text { Kayfa ḥāluk 'ant } \\
& \text { A: الحمد له 'alḥamdu lillāh } \\
& \text { كيف الأهل Kayf 'al'ahl } \\
& \text { B: بخير الحمدلله bihhayr 'alhamdu lillāh }
\end{aligned}
$$

Literal translation
A: Peace be upon you.
B: And peace be upon you.
A: How are you.
B: Praise be to Allah.
How are you.
A: Praise be to Allah;
How is the family?
B: Well, praise be to Allah. 
A non-vernacular translator of an SL text may not thoroughly understand the paralinguistic information of SL phatics, misinterpret the pragmatic meaning of a lexical unit and fails to reproduce an equivalent SL lexical function in the TL text. Within the lines of phatic expressions, Beridze identifies word-realies that are not translatable. Many of these exotic foreign honorifics turn into borrowings which, in general, are transcribed in translation. For example, effendi is a Turkish honorific suffix of the first name of the addressee which bears national colouring and thus it is transcribed or transliterated with the ensuing sense of foreignism. But should an average English reader be culture-sensitive enough to identify 'Turkish' honorifics without a footnote definition? If not, it is unlikely that the TL reader would be able to realize the socio-cultural value of effendi as an authentic source honorific. Even more inadequate it would be to transpose a marker of distance with a marker of solidarity. For example, while the address titles 'sir' and 'mister' express distance, respect and formality in English, their direct lexical equivalent Batono in the Georgian language community stand as markers of intimate phatic communion (Beridze: translationdirectory.com/article1200).

\section{The dichotomy of phatic expressions: Cooperative maxims vs. conversational politeness}

Grice's maxims of the Principle of Cooperation, which include quantity, quality, relevance and manner, do not seem to apply in the case of phatic expressions on the grounds that Grice was not originally concerned with phatic communion. He seems to be considering framed conversations where there is an immediate goal or set of purposes, mutually-accepted by the participants (Grice 1975: 48)

Phatic communion does not always signify lexical inferences. Within a literal interpretation of Leech's Economy Principle (Leech 1983: 67), one may presume that phatic expressions are a case of redundant tautology and, therefore, should be 'reduced where possible' as their elimination does not lead to ambiguity of message. In the words of Newmark (1988: 208), such superfluous expressions should be pruned:

"...Redundancies hang particularly loosely around clichés, phatic phrases ('phaticism'), repeated implied superlatives, prepositional phrases, rhetorical flourishes...Normally, the translator has to use restraint in excising redundant SL features, confining himself to pruning here and there, since if he goes too far he is sometimes likely to find the whole text redundant."

Darwish (2003: 50-1) cites the example of the honorific pronouns such as usted in Spanish and vous in French ( سيادتكم siyādatukum / أنتم / حضرتكم haḍratukum 'an an in Arabic) which are used for the second person singular to represent an embedded system of politeness that denotes rank, status and social distance of speaker and addressee. $\mathrm{He}$ proposes that the translator must decide whether (SL) cultural redundancies are essential for the message to be communicated effectively in a target language like English that lacks such honorific pronouns. He remarks that the dogmatic adherence to literal translation of cultural and emotive redundancies has created the misconception in the 
eyes of western readers who have come in contact with Arabic through translation that Arabic is a 'flowery' language (Ibid).

It seems that the views cited above evolve around textual equivalence more than discoursal efficacy for the message to be communicated is not solely verbal. The sociocultural aspect in phatic rituals often denotes a desire by the interlocutors to establish communication rather than simply impart lexical meaning. The fact that most phatic expressions aim at enhancing politeness and saving face by employing positive formulae such as flattery or apology, may flout Grice's maxims of cooperative principles that include quantity, quality, relevance and manner. In other words, an analysis of conversational discourse would reveal that most phatic clichés are not exactly concordant with the face value of their lexical interpretation. If so, then this would be considered a manipulation of the maxim of truth and relevance. However, Grice's maxims "are essentially ground rules for the interactive management of intentions" (Widdowson 1998: 13). Hence, they can be expanded to include the maxims of politeness such as tact, modesty and intimacy for without phatic expressions such as greetings, flattery and apology, sustaining a dialogue will be almost impossible. Therefore, it can be safely said that phatic expressions have relevance to the sociolinguistic function of communication and the conventional modes of culture. The interlocutors in a given communicative discourse need to determine their sociability level in order to map the trajectory of their dialogue. The cosmetic effect of phatic communion defuses tension and makes a request for information looks as a form of inquiry rather than an imperative imposition (Abu Hatab 2006: 20).

Consequently, any interpretation of phatic expressions should be viewed within

a pragmatically dynamic schema of discourse. Rather than simply a static product within the immediate text, phatic communion is an ongoing interaction in the making. Interactants are not free agents who can alter social norms and etiquette nor do they simply quote conventional phatic clichés without individual engagement. Certainly, they are constrained by established conventions and customs, and restrictions are set on their initiative but there is always room for maneuver. In order to render a given phatic expression accurately in terms of relevance and cultural functionality, a translator needs to assess the situation that produces it. For instance, in case of an apology, one needs to understand the intention behind it, and its likely effects. It is only in context that speakers are able to recognize whether, for example, an utterance of "I'm so sorry" is to be taken as an expression of apology, regret, condolence, or sarcastic defiance (Davies et al. 2004: 164).

\section{Socio-pragmatic variables}

There are certain variables that govern the choice of formulaic openings and closings such as translation purpose (skopos), genre conventions, setting, age, sex, rank, social/ financial status, education and degree of intimacy. For example, the closing phrase شاء اله 'inšăa'a 'Allah [God willing] can be interpreted differently according to age, the degree of intimacy or respect among the interlocutors. If the phrase is uttered as a response to a command by a speaker of a higher social status or rank (e.g. a superior in a corporate) or of an older age, it would carry the force of a speech act and forms a commitment to execute the command promptly; it would be approximately translated as 'certainly', 'definitely' or 'absolutely'. However, if the same phrase is used in response to 
a request by someone who is of equal or inferior status, then it would not necessarily constitute a moral obligation and it would better be translated as 'ok', 'alright', 'I'll see what I can do', 'I'll let you know'.

Generally speaking, the older the speaker the more likely s/he would be inclined to use phatic expressions. Thus nowadays, the complimentary phrase يرحمك اله yarhamka 'Allāh [may Allah have mercy on you] or 'bless you' in English, which is uttered after the addressee sneezes and says الحمد له 'alhamdu lillāh [thanks/ praise to Allah], is rarely used by the pragmatic, internet generation who prefer to ignore the whole act of sneezing as simply a physical reflex to a given stimulus. Likewise, phrases like بارك اله فيَك bāraka 'Allāhu fīk [may Allah bless you], اله يرضى عليك 'Allah yirḍa 'alaik [may Allah

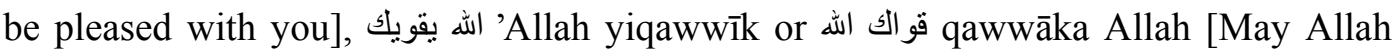
give you strength] are age/status-restricted since they are often uttered by an older speaker (or a senior of higher rank) to a younger one (or a junior of lower rank). In contrast, the phrase طويل العمر tânīl al amrak or 'umur [May you be blessed with long life] is used initially or finally upon addressing old people or those of higher status.

In the same way, young people often use the title شيخ [sheikh] حجي hağği [pilgrim] and عمي 'ammiy [my uncle] to address senior citizens even though the addressee may never have performed the pilgrimage and is in no way related to the speaker. Ironically, speakers of a Lebanese or Syrian dissent use a similar word بابا bâba [father/daddy] to call young children as a way of emulating child talk. Finally, upon يالله concluding a conversation, an old (male or female) speaker may use the expression yâllah husn 'alhāātmah [May our lives have a blessed ending]. Yet, younger تأمر أي ay hidmah [any service/I'm at your service] or أي خدمة people use the expressions شيء tā'mur 'ay šay' [would you like to order/ request anything] to address people of older age or higher status. Unfortunately, such phatic expressions have no direct translational equivalents in English and they are either given a literal rendition or are ignored altogether.

Abu Hatab (2006: 27, 31) notes that compliments are more frequent in the discourse of [middle-aged and old] females regardless of the age, sex or social status of the addressee. Indeed, there are sex-specific phatic expressions and compliments that are female-oriented. The compliment يجّب yihabbil [out of this world/astounding/mind boggling] which is used by some communities in the Arabian Gulf countries indicates that the speaker is feminine for if it is, otherwise, uttered by a male it will connote that he is effeminate. Therefore, a translator should exercise caution when rendering equivalent English expressions into Arabic. If it transpires that the speaker is a male the

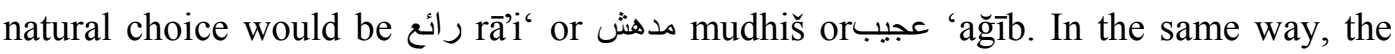
'goodbye' alternatives in Arabic include في أمان اله مد السلامة ma'a 'amān 'Allāh and 'assalāmah whereby the latter is often uttered by females. And when concluding a conversation in the Arabian Gulf region, a female speaker is likely to say الكلام معاك ماينمل 'ilkalām ma‘āk māyinmal [It's nice/ interesting talking to you]. Again, a translator has to determine the sex of the speaker before embarking on any one choice.

In terms of the degree of intimacy, a distant male would use a brief greeting such as

marhaba [hello] or a zero 
greeting, followed by a simple من فضلاك min faḍlik لو سمحت/ law samaht [please] or مكن... mumkin ballah [by Allah, can...] before addressing his request to a male peer (Abu Hatab 2006: 32). The same distancing level occurs when the speaker is a female and the addressee is a male. Yet, if a male addresses a female and vice versa, s/he would prefix his or her request with more ice-breaking polite expressions such as sكumkin ، لو سمحت law samaht [excuse me, would you kindly...]. By modifying the standard formal greetings, one may indicate a special intimacy level as when young males address young females (often with a flirting intent) with the greeting صباح الورد șabāh 'alward [morning of roses] or صباح القشدة ياعل șāḥ 'ilqišdah yā'asal [morning of cream $\mathrm{O}$ honey] which is almost the equivalent of the English 'good morning honey' less the cream. However, a simple formal 'good morning' may be combined with other lexical items or uttered with a special intonation to convey negative connotations. Thus for example, a rising tone on the word 'morning' or the addition of the word 'Beirut' would add sarcastic overtones as in the pod article entitled صباح الخير يابيروت 'sabāh ilhair yābayrūt [Good Morning O Beirut !!] (منتدى الطيران العربي) which is intended to criticize the status quo in Lebanon.

Similarly, setting, distance and the number of participants involved would influence the choice a phatic formula. Thus, the opening phrase الله يعطيك العافية 'Allah ya'tīk al'āfyah [may Allah give you health] is addressed to an employee or a labourer before placing a request. However, with a high pitch and a rising intonation, the same expression can be used in Syria and Jordan to indicate mockery and reprimand when the addressee is blamed for a grave mistake. Another setting-related example is the greeting السلام عليكم ورحمة اله وبركاته 'assalāmu 'alaykum wa raḥmatu 'Allāhi wabarakātuh [may peace, the grace and blessings of Allah be upon you]. Although, a participant in a conference held in an Arab locale may open his presentation by this traditional formal greeting, an interpreter would rather render the greeting as "good morning" or "good afternoon/ evening" lest the literal translation of the original carries some unintended religious nuance. By the same token, the use of the time-free greeting الله بالخير 'Allah bilhair [by Allah's grace] is more frequent among males in the Arabian Gulf region and is mainly used in male-to-male conversation. However, in translation, such a greeting would rather be rendered as 'hello' or 'hi' for the same reason mentioned under السلام عليكم ورحمة الهه وبركاته

Topic-related phatics abound in (dialectal) Arabic. Upon receiving a favour or a nيض اله رايتك بيضا rāytik baiḍah [may Allah make your face white] or بارك الله فيك الك الك خير ا gārazāka 'Allāhu hayran [may Allah reward you with His blessings] which can be translated by a simple 'thank you' or '(I) appreciate it'. Further, after delivering a baby, either parent is congratulated in one of the following: الحمد اله على السلامة 'alhamdu Lillāh 'ala 'assalāmah [praise to Allah for your well being] or مبروك ما جاكس mabrūk māğāk [congratulations for what you have been جعله الله من أبناء yiven] or يتربى بعزك yitrabba bi'izzik [may he be raised in your honour] or ğa 'الذرية الصالحة righteous/ pious son]. In English, a single word of 'congratulations' will be sufficient. Likewise, upon surviving an accident or after undergoing surgery, visitors will often 
resort to expressions that involve religious nuances such as خطاك السو hatāk 'assuw [may

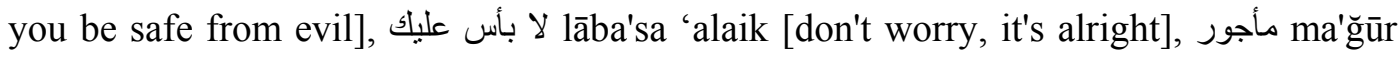
[all for a good reward], أجر و عافية عالِية 'ağr wa 'āfyah [may you be rewarded and blessed with

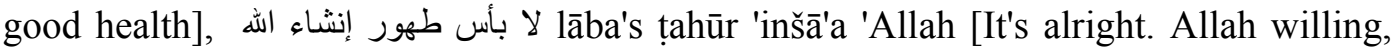

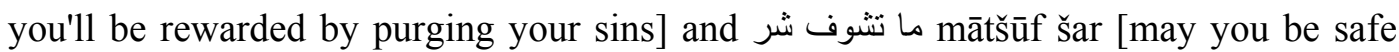
from evil]. The latter has been extended to occasions that do not involve accidents or sickness and it has become more of a casual greeting as a filler or floor control device in conversations. For all the above, English uses fewer and shorter equivalents such as 'get well soon' and 'wishing you good health'. Naturally, the English translation will lose the versatility and the religious nuances relayed by the Arabic originals.

Another topic-related phatic expression is بيتكم 'albait baitkum [the house is yours] 'feel at home' which is used during welcoming visitors to one's home. It should be noted, however, that in the event of a first visit to a recently purchased house, the visitor should initiate the conversation by the compliment منزل مبارك manzil mubārak [may it be a blessed home] which translates into the broad-spectrum complimentary greeting in English 'congratulations', even though the Arabic expression carries religious overtones quoted from a similar verse in the Quran. Within the same context, sufra dāymah [may yours be an everlasting table] is uttered by the visitor after having a meal to thank the host for his/her hospitality. The equivalent English expression would be something in line with 'thank you, that was a delicious meal'.

Geographical location and gender may combine to determine the type of phatic expression. In concluding a transaction at any commercial facility, a male salesman in the East of the Mediterranean region may thank a male customer by saying معوضين m'awwaḍin or الله يعوض عليك 'Allah y'awwiḍ 'alaik [may Allah recompense you]. Yet such a phrase would rarely be used when either or both participants are females. Instead, it will be replaced by a simple شكر آ شكrukran [thank you] or the borrowed French formula 'merci'. The latter is also governed by the factor of education and liberalism since a religiously conservative female of the same region would prefer the Arabic to the French equivalent. An interpreter translating any of these formulae into English would rather avoid the intricacies of these fine variables and render the closing phrase as 'thank you'.

Gender has also been found as a governing factor in the use of profanities and curses in phatic expressions. Females tend to use more standard expressions with lesser taboo forms. They are more likely to express positive politeness and to use mitigating strategies in order to skirt or dilute threats to an interlocutor's face. On the other hand, masculinity is emphasized through the use of taboo (colloquial) words (Abu Hatab 2006: 42). Females may also resort to code-mixing between English and Arabic phatic formulae as a signal of high class and prestige (see the section on 'lost in translation' below).

\section{5, Lost in translation: Phatic anomalies}

What might be appropriate in one language might not be so in another since phatic rituals are informed by cultural conventions and social customs. It follows that transposing SL phatic peculiarities will create a sense of foreignism if no functional matches exist in the recipient language. Likewise, failure to reproduce the effect of such 
peculiarities into the TL will lead to unredeemable loss in translation. In his study of politeness in Catalan, Parent (2001: 597) indicates that loss in translating phatics is inevitable since some requests for information may be void of any preamble greetings such as 'hello' or 'excuse me', 'please' or even the closing 'thanks' after the addressee's response. He ascribes this to the urgency of the request and the immediacy of the response which may take place in such settings as near an elevator or a crowded passage in a shopping mall. In order to soften or mitigate the 'face-threatening' imposition, the speaker uses a compensatory intonational contour with a 'polite' sound pitch. Yet, upon the reproduction of such an exchange in a written script the non-verbal features will be lost and the request may sound abrupt

In both English and Arabic, speakers start a dialogue by using rhetorical questions such as 'haven't I seen you somewhere before?' which has a direct equivalent أنا يتهيأ لي إني شايفك قبل هذه المرة yithayya'liy 'inniy šāyfik qabl hāthihi 'ilmarrah or Arabic anā mšabbih 'alaik [you look like someone I know]. The question/answer ritual about the wellbeing of the addressee also exists in both languages albeit with a higher frequency in Arabic. Likewise, the initial greetings are more elaborate in Arabic with questions ranging from the health of the addressee, the wellbeing and whereabouts of his sons, brothers, family, friends and acquaintances, his job and even the address of his current residence. Similar questions about the health of the addressee or some private family matters are repeated out of context at intervals in the middle of a conversation in order to fill pauses, mark a topical shift or simply as a gambit to keep the communication channel open. Translating such semantically 'redundant' phatic interrogatives would sound awkward in English and they will definitely be culturally marked as Arab interactants tend to use the seemingly superfluous phatics to develop solidarity more readily than English speakers. This is probably why Arabic goodbyes tend to end with phrases while one word is enough in English (Abu Hatab 2006: 41).

One function of phatic communion is to show social solidarity. Therefore, it is not unusual to find that they are frequently infiltrated by dialectal and foreign words. However, since there is no standard gauge for rendering a given non-standard variation in Arabic by an English dialectal equivalent, a translator will either use a standard TL equivalent or a dialectal (slang) approximate. In both cases, the target rendition will reflect a style shift. Thus for example, a phrase like 'shut up' has a different meaning

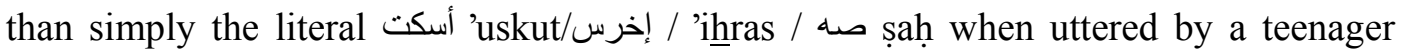
expressing admiration towards his/her peer as in 'shut up! This is a masterpiece' wherein the translation should preserve the complimentary overture as in ياللروعة yâlarraw'ah [fantastic], إنها تحفة 'Allāhnahā tuhfa [it is a masterpiece] or 'إلله ، إنها حقا رائعةً 'nnahā haqqan rāi' ‘ah [by God, it is indeed marvelous].Likewise, A Kuwaiti youth may admire his male peer's new car by cursing or calling names to express high solidarity يلعن يومها صنت على كل موديلات السبورت yil'an yūmha șakkat 'ala kil 'ilmūdailāt [damn its day, it beat all sport models]; an Egyptian would use a similar phrase يخرب بيتها دي ضردبت كل yihrib baitha di ḍarabit (farkišit) kul il'arabiyyāt lisbūr [may its house lay in ruins, it beat all sport cars]. The nearest approximate translation in English would be 'wow, it beat all sport models!' or 'damn, it's a knockout!' or even "it kicks a...'. A young female, however, may use more filtered expressions and show her admiration by saying واي تهبل wāy 'ithabbil 'gosh, it's a swell !' Indeed, colloquial and 
taboo phrases like الهه يلعنك 'Allah yil'ank [Allah Damn you] and اله ياخذك 'Allah yāhdik [May Allah take your soul] are sometimes used to show group affinity and peer bondage especially among males who want to assert their masculinity. Such variations require that the translator be well-versed in the regional dialectal variations throughout the Arab countries and be able to relay the connotations rather than the denotations of phatic expressions especially in the presence of taboos and pseudo-curses which carry no acrimonious or bitter feelings at all. Nevertheless, there will always be an unredeemable loss in respect of the paralinguistic associations of locale and variations of regional colloquials that have no equivalents in the target language

Another loss in translation occurs upon translating code-mixed phatic expressions. The latter are most noticeable in female colloquial speech as a marker of prestige and high class. Young educated females have a tendency to insert foreign (mostly English or French) lexis to initiate or end their phatic expressions,

e.g. بونجور، كيف المدام اليوم būnğūr kaif 'ilmadām 'ilyūm [bonjour, how is your madam (wife) today]

mumkin ta'ṭini 'ilmūbāyl please [can you give me the mobile please]

Ok nšūfak ba'dain, bye [Ok. See you later, bye].

The effect of using code-mixing to convey a sense of prestige and high class is purged in the English translation as borrowed lexis are restored to their original unmarked status. This is a case of unamendable loss that can only be rectified by annotation.

\section{Cultural disparity: A case of under-translating}

Compared to English, Arabic has a much more versatile inventory of phatic communion expressions. However, this does not entail that the issue of cultural disparity will automatically lead to untranslatability. Rather, it is possible to find functional equivalents even though the length of the target rendition may not match that of the source text. Generally speaking, the majority of phatic expressions in Arabic is cast in phrases rather than single words. Some of these expressions originate in the standard 'classical' version of Arabic while a good number are formulated in the colloquial(s).

Arabic phatic formulae tend to be permeated with religious nuances that constitute untranslatable loopholes when rendered in English where functionally corresponding formulae do not contain such references. Translators, therefore, tend to render ad verbatim or alternatively simplify the ST by using superordinate terms in the absence of equivalent hyponyms in the TL. For example, the simple greeting word 'Hello' can be rendered as السلام عليكم 'assalām 'alaykum [peace be upon you] or الله بالخير 'Allah bilhair [with the good of God] in the Kuwaiti and Iraqi dialects, while the Lebanese-Syrian equivalent مرحبا marhaba [welcome] is used erroneously by the addressor instead of the addressee (74). Likewise, upon requesting and thanking, An Arab may use الله يخليك فيك bāraka 'Allāhu fîk [blessings of Allah upon you] for which English would use the generic 'please', 'would you kindly...' or 'thank you'. Jones (1999: 5) cites the honorific الثيخ 'Sheikh' which is used by Christian-oriented Lebanese newspapers to refer to the former Philangist leader as الثيخ بيار الجميل. A culturally equivalent translation would 
omit the Arabic honorific and retain 'Pierre Gemayel' as there is no association of respect in the Islamic title الثيخ 'sheikh' to warrant including any equivalent in the TL. Similarly, on the occasion of buying a new car, English speakers use a simple compliment such as 'congratulations' while in Arabic and its dialects the equivalent can be made more elaborate: مبروك، اله يكفيك شرها mabrūk, 'Allah yakfîk šarha [congratulations, may Allah spare you its troubles/evil]. A speaker is also expected to pass an anti-envious remark such as ما شاء الله māšā'a 'Allāh [blessed is the will of Allah] or تبارك الرحمن tabāraka 'arraḥmān [blessed is Allah]. Even in simple matters as when the

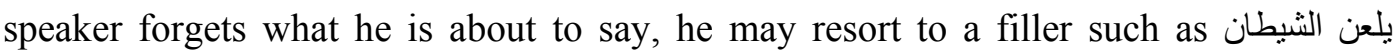
yil'an 'iššaițān [cursed is the devil] or اللهم صل على النبي 'Allāhumma șalli 'ala 'innabiy [Allah's blessings be on the prophet]. The latter may also be used in an imperative form s șalli 'ala 'innabiy as a floor marker to soothe the addressee and request turn taking. Indeed, there are many situations in which an Arab speaker uses an imperative construction while intending to convey a polite request or invitation as in offering a ride سم wam [utter: 'in the name of Allah'] and مد إركب mid `̃dik [dig in].

Under-translation is also present in other settings like dining and inviting guests to a meal. For instance, if the loan phrase 'Bon appetit' is translated into 'good appetite' when sitting at a table with an English friend, it would sound semantically correct but socially and culturally wrong (Bassnet 751). A more natural equivalent would be 'enjoy your meal' or 'please, help yourself'. In the same way, its Arabic renditions طعاما شهيا 'ally ta‘āman šahiyyan or the literal [شهية طيبة šahiyya țayyibah] do not sound culturally correct as it is customary to say تفضلوا tafaḍalū [please, help yourselves], مد يدكة mid ‘̄dik [dig in] or بالعافية bil'āfyah [with good health]. Similarly, while it is the tradition in English to say the graces followed be 'Amen' before a meal, it is customary in Arabic to begin by uttering the phrase بسم اله bismi 'Allāh [in the name of Allah] and end by الحمد لे 'alhamdu lillāh [Praise be to Allah] which have no functional equivalents in English. After a meal, guests are expected to compliment their host in English by phrases like 'thank you, that was a delicious meal...' whereas in Arabic the guest says سفرة دايمة sufra dāymah [May it be an everlasting feast] or اله يديم النعمة Allah yidīm 'anni'mah [May Allah perpetuate His grace]. In funerals, mourners may use phrases like 'I'm sorry. Please accept my sincere condolences' while the equivalents in Arabic carry religious overtones as in lāhawla walā quwwata 'illā billāh [No power save

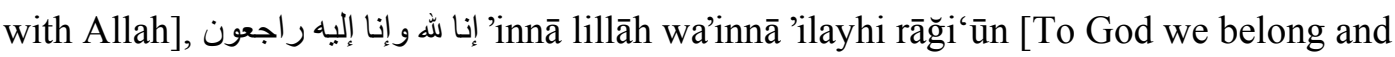
to Him we return], عظم اله أجركم 'aẓzam 'Allāh 'ağrakum [May Allah exalt your reward],

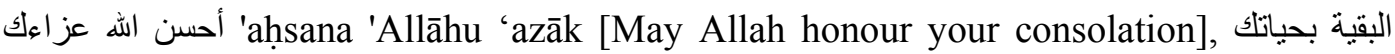
(البقى بر اسك) 'ilbaqiyyah biḥayātik ('ilbuqa brāsik) [May you be recompensed in the rest of your life] or سبحان الحي الباقي subhāna 'alhay 'albāqī [glory to God the Eternal the Immortal].

The case of under-translation extends even further to the phatic rhetoric of written letters. Arabic letters often open with the ceremonial invocation بسم اله الرحمن bismi 'Allāh 'arraḥmān 'arraḥīm [In the name of Allah Most gracious Most 
merciful] for which English has a zero equivalent. Likewise, the opening salutation 'Dear...' in a formal English letter is (mis)matched by a more somber equivalent in Arabic المحترم 'almuhtaram 'Esquire' while the English complimentary close 'with best regards' is rendered as وتفضلو ا بقبول فائق الإحترام watafaḍ̣alū biqubūl fā’iq al'ihtirām [please accept our utmost respect] which indicates a higher level of formality. It is also customary in Arabic application letters to insert a concluding phatic statement whereby the addresser expresses his gratitude towards the addressee and invites a favorable consideration of his request or application. Even the signature line is void of the phrases 'sincerely yours' or 'truly yours' as Arabic signatures are limited to the sender's title and professional rank. All the above examples point towards the fact that it is fallacious to contemplate a faithful rendition of phatics and that instead of mistranslation we may opt for under-translation as a compromise.

\section{Proxemics, kinesics and phatic gestures}

Bronislav Malinowski's (1923) definition of phatic communication is somewhat restricted to the oral verbal level. Yet, audible verbal expression is but one form of communication. To successfully conduct a conversation, participants must display a willingness to collaborate and reciprocate through other non-verbal means such as maintaining a friendly body posture, showing attention and avoiding any unnecessary interruptions or disruptive remarks. Although only one participant is allowed to speak at a time, the addressee may react by facial expressions, headnods, touching behaviour and physical gestures to respond to many functions such as greeting and leave-taking, affection or aggression, attraction, gratitude and congratulation. For instance, if a participant leans backward, this might be a signal that he or she wishes for the conversation to end. If a co-participant reacts by leaning forward, the conversation must continue in its present phase. In this fashion, co-participants can move together into successive phases of the event which are much more easily identified with the individuals who utter them, independent of verbal suggestions and commitments (Lockard et al. 1978: 224). Simply being responsive, in any way, to others' adjustments in spatial-orientational positioning sends a message of engagement, another function of phatic communion.

Another non-verbal expression of phatic communion is eye-contact. Coparticipants repeatedly focus their eyes on different parts of the face and, occasionally, their eyes meet. The aiming of the eyes is perhaps the principal way in which the interactants can signify their attention and engagement. Indeed, one of the ways in which a recipient of an utterance may shift topic or redirect the speaker to another point is by looking away from the speaker and towards another member of the gathering (Kendon 1992: 332). Nevertheless, it is customary in an Arab society to avoid head-on eye-gaze which may be construed as defiant or rude especially when the conversation occurs between a male and a female. It is courteous to shift the eye intermittently without losing sight of the co-participant.

Although some proxemics are of a universal nature, others vary in their interpretation from one culture to another as they operate within certain social constraints. For instance, the standing distance between a male and a female is closer in a European society than in a conservative Arab setting where heterosexual interactants keep a safe distance. Moreover, North European societies avoid frequent touching while 
Arabs tend to tolerate it among individuals of the same sex (Crystal 1987: 401). Greeting embraces and kisses (on the cheeks or the nose) among males are done more frequently in an Arab society even if the period of absence is as short as two or three days. Sometimes embraces are performed twice within the same session, both upon greeting and leave-taking. Fine differences also exist between tribal Bedouins who prefer to kiss one cheek only and urban dwellers who alternate between two cheeks. Nose kissing is performed when the recipient is older in age or higher in status.

Gender differences are also present in performing greeting proxemics in an Arab society. While embraces are common between females they are not allowed between a veiled woman and a man unless they are closely related. Similarly, a man may not shake hands with a veiled female unless she takes the initiative by extending her arm. Any misinterpretation of proxemics can easily lead to embarrassing situations that may affect the progress of a conversational routine.

\section{Conclusion}

The study has revealed that although Arabic and English share some similarities with regard to the selection variables of phatic expressions, there are differences that are manifest in the structure and frequency of the formulae used. Thus, while Arabic uses more complimentary phrases English relies on single words. Likewise, the frequency of both lexical and non-lexical expressions is higher in Arabic.

The examples cited in this paper indicate that it is fallacious to contemplate a faithful rendition of phatics and that instead of mistranslation we may opt for approximates or even under-translation as a compromise on the relative scale of correctness. Our findings attest to the fact that the study of translation can never be entirely scientific or value-free. Like any ethno-cultural study, translating phatic expressions involves the creative reproduction of values within the constraints of pragmatics, semiotics and the socio-cultural background of the interactants.

The socio-pragmatic aspect of phatic expressions is still an underexplored area. Future studies may be channeled to develop a taxonomy of phatic strategies and their corresponding expressions in both English and Arabic. Such a taxonomy should involve a contrastive socio-pragmatic analysis of phatic discourse with a view to diagnosing the sources of mistranslations and cultural mismatches. Research is needed to see if there is a correlation between the frequency of phatic expressions and the variables of topical choice, register and the interlocutors' socio-cultural background. For instance, one contested assumption is that phatic clichés thrive in lesser educated and rural communities and that the co-participants' profession is one of the important variables that determine the level of phatic expressions.

Further investigation is needed to explore the role of honorifics, titles, intonational patterns, proxemics and kinesics in the constitution and interpretation of phatic communion across languages and cultures. Such a study may also examine the influence of acculturation through the globalization of mass media. 


\section{References}

Abu Hatab, Wafa Ali (2006) Phatic communion in Arabic and English. Spoken discourse; implications for interepretrs". Translation Watch Quarterly. Australia, Victoria: Translation Standard Institute. Vol. 2, Issue 3, Sept 2006.

Al-Khasawneh, Maha (1996) The translatability of phatic expressions in Jordanian Arabic into English. MA. dissertation, Yarmouk University, Amman, Jordan.

Bassnett, S. (2001) Variations on translation. In La Linguistica Applicada A Finales Del Siglo XX, AESLA, Universidad De AlCala., Salamanca, Spain, pp. 749-758.

Beridze, Khatuna. The importance of adequacy in translation http://www.translationdirectory.com/article1200.htm. Accessed on 25/10/2008

Cheepen, C. (1988) The Predictability of Informal Conversation. London: Pinter Publishers.

Coulmas. F. (ed) (1979) Conversational Routine: Explorations in Standardized Communication Situation and Prepatterned Speech. The Hague/New York: Mouton.

Crystal, David. (1987) The Cambridge Encyclopedia of language. Cambridge: Cambridge University Press.

Darwish, Ali (2003) The Transfer Factor. Melbourne: Writescope.

Davies, Alan, and Catherine Elder (eds.) (2004) The Handbook of Applied Linguistics. Oxford: Blackwell Publishing.

Denzin, N.K., and Y.S. Lincoln (2000) Handbook of Qualitative Research. Thousand Oaks, CA: Sage.

Dickins, J., S. Hervey, and I. Higgins (2005) Thinking Arabic Translation. London and New York: Routledge.

Gozales, Luis Perez (2001) Strategic moves for the convergence of interactional agendas in pragmatic conversation. In La Linguistica Applicada A Finales Del Siglo XX, AESLA, Universidad De AlCala., Salamanca, Spain, pp. 603-607.

Grice. H.P. (1975) Logic and conversation. In P. Cole, and J.L. Morgan (eds), Syntax and Semantics 3: Speech Acts. New York: Academic Press.

Holmes, J. (1995) Women, men and politeness. London: Longman.

Jackobson, R. (1960) Closing statement: Linguistics and Poetics. In T.A. Sebeok (ed.), Style in language. Cambridge, MA . MIT Press.

Jones, L. (1999) Translation of الحاج رئيسا للكتائب بفارق 7 أصوات (from النهار newspaper, 2 march 1999. BA translation project: University of Durham.

Kendon, Adam The negotiation of context in face-to-face interaction. In Alessandro Duranti \& Charles Goodwin (eds.), Rethinking Context: Language as an Interactive Phenomena. Cambridge: Cambridge University Press, pp. 323-34.

Laver, J. (1975) Communicative functions of phatic communion. In A. Kendon, R. Harris and M. Key (eds.), The organization of behavior in face-to-face interaction. The Hague: Mouton, pp. 215-238.

Leech, G.N. (1983) The Principles of Pragmatics. London: Longman. 


\section{Jamal B.S. al-Qinai}

Lockard, J., D. Allen, B. Schiele, and M. Wierner (1978) Human postural signals: Stance, weight shifts, and social distance as intention movements to depart. Animal Behavior 26: 224.

Malinowski, B. (1923) The problem of meaning in primitive languages. In C. Ogden and I. Richards. The Meaning of Meaning. London: K, Paul Trench., Trubner and Company, pp. 296-336.

Miller, E. (1999) Turn taking and relevance in conversation.

http://ccat.sas.upenn.edu/ emiller/index.html

Mughazy, Mustafa (2000) Pragmatics of the evil eye in Egyptian Arabic. Studies in the Linguistic Science. 30.2: 147-157.

Nelson, G.L., W. El-Bakary, and M. Al-Batal (1993) Egyptian and American compliments: A crosscultural study. International Journal of Intercultural Relations. 17: 293-313.

Newmark, Peter (1988) A Textbook of Translation. London: Prentice Hall.

Oleksy, W. (1989) Contrastive Pragmatics. Amsterdam/Philadelphia: John Benjamins Publishing Company.

Parent, Monteserrat Perez I. (2001) Some considerations on politeness in Catalan service encounters. Trabajos en Linguistica Aplicada. AESLA, Barcelona, pp.597-604.

Robins, R.H. (1964) General linguistics. London and New York: Longman.

Sanchez, Ana Lopez (2001) Trabajos en Linguistica Aplicada. AESLA, Barcelona, pp.591-6.

Schneider K. (1988) Small Talk: Analysing Phatic Discourse. Marburg Germany: Hitzeroth.

Widdowson, H.G. (1998) The conditions of contextual meaning. In K. Malmkjer \& J. Williams (eds.), Context in language learning and language Understanding. Cambridge: Cambridge University Press, pp. $1-23$.

Wierzbicka, A. (1985) Different culture, different languages, different speech acts. Journal of Pragmatics 9: $145-178$.

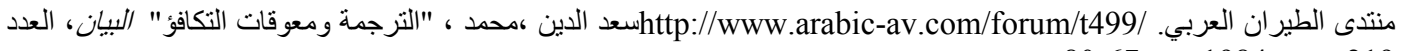
219، يونيو 1984، ص الطيرن 197

\section{Transliteration Symbols}

\begin{tabular}{|c|c|c|c|c|}
\hline 1 & , & $\varepsilon$ & $15 \mathrm{~d}$ & ض \\
\hline 2 & $\mathrm{~b}$ & ب & $16 \mathrm{t}$ & $b$ \\
\hline 3 & $t$ & ت & $17 \mathrm{z}$ & b \\
\hline 4 & $\underline{t}$ & $\dot{H}$ & $18^{\prime}$ & $\varepsilon$ \\
\hline 5 & $\breve{g}$ & ج & $19 \dot{\mathrm{g}}$ & $\dot{\varepsilon}$ \\
\hline
\end{tabular}




\begin{tabular}{|c|c|c|c|c|}
\hline 6 & h & $z$ & $20 \mathrm{f}$ & ف \\
\hline 7 & $\underline{\mathrm{h}}$ & $\dot{k}$ & $21 \mathrm{q}$ & ق \\
\hline 8 & d & 2 & $22 \mathrm{k}$ & ك5 \\
\hline 9 & $\underline{\mathrm{d}}$ & $j$ & 231 & $J$ \\
\hline 10 & $r$ & P & $24 \mathrm{~m}$ & م \\
\hline 11 & $\mathrm{z}$ & j & $25 \mathrm{n}$ & $\dot{~}$ \\
\hline 12 & $\mathrm{~S}$ & w & $26 \mathrm{~h}$ & 。 \\
\hline 13 & $\check{S}$ & ش & $27 \mathrm{w}$ & 9 \\
\hline 14 & Ș & ص & $28 \mathrm{y}$ & ي \\
\hline
\end{tabular}

Long vowels: $\bar{a} \overline{1} \bar{u}$

Short vowels: a i u

JAMAL AL-QINAI is an Associate Professor of translation and contrastive analysis at the Department of English Language and Literature, Kuwait University. He has published several articles on translation quality assurance, transliteration, modality in translation and morphophonemics of loanwords in journals such as META, Babel, VIAL, AUMLA, ITL, and Pragmatics. His current research priorities focus on intercultural mediation and discourse divergences.

Address: English Department, Kuwait University, P.O. Box 2324, Hawalli 32024, Kuwait. E-mail: jamalqinai@hotmail.com 